\title{
Erratum to: Study on injury effect of food additive citric acid on liver tissue in mice
}

\author{
Xiaoguang Chen • Qiongxia Lv • \\ Yumei Liu $\cdot$ Wen Deng
}

Published online: 3 May 2016

(C) Springer Science+Business Media Dordrecht 2016

\section{Erratum to: Cytotechnology (2014) 66:275-282 DOI 10.1007/s10616-013-9567-1}

Unfortunately, in the original publication of the article, the citation and the corresponding reference appeared incorrectly as below:

Citation: Koca et al. (2005) reported that citric acid could significantly increase micronucleus frequency in red blood cells of Tinca tinca.

Reference: Koca YB, Koca S, Yildiz S, Gürcü B, Osanç E, Tunçbaş O, Aksoy G (2005) Investigation of histopathological and cytogenetic effects on Lepomis gibbosus (Pisces: Perciformes) in the Cine stream (Aydin/Turkey) with determination of water pollution. Environ Toxicol 20:560-571

The correct citation and reference are given below:

Citation: Koca et al. (2010) reported that citric acid could significantly increase micronucleus frequency in red blood cells of Tinca tinca.

Reference: Kocak Y, Gaffaroglu M, Yuksel E (2010) In vivo micronuclei induction by food additive citric acid in peripheral erythrocytes of the fish Tinca tinca. Fresen Environ Bull 19(8a):1608-1614.

The online version of the original article can be found under doi:10.1007/s10616-013-9567-1.

X. Chen $(\bowtie) \cdot$ Q. Lv · Y. Liu · W. Deng Animal Science and Technology School, Henan University of Science and Technology, Luoyang 471003, Henan Province, China e-mail: cxguang1015@126.com 